\title{
GREATER COHESION IN AN INCREASINGLY FRACTURED WORLD: WHERE NOW FOR THE EUROPEAN PROJECT? Report on the EUROFRAME 2019 Conference
}

\section{Catherine Mathieu and Henri Sterdyniak}

Sciences Po, OFCE

"Greater cohesion in an increasingly fractured world: Where now for the European project?". This was the theme of the 16th EUROFRAME Conference on economic policy issues in the European Union, which was held on 7 June 2019 in Dublin. EUROFRAME is a network of European economic institutes that includes: DIW Berlin and IfW Kiel (Germany), WIFO (Austria), ETLA (Finland), OFCE (France), ESRI (Ireland), PROMETEIA (Italy), CPB (Netherlands), CASE (Poland) and the NIESR (United Kingdom). Since 2004, EUROFRAME has organized an annual conference on an important subject for Europe's economies. In 2019, 27 researchers made presentations, most of which are available on the conference website. This article provides a summary of the work presented and discussed during the conference.

As the title of the conference emphasizes, the year 2019 has been marked by the risk of fractures in the world economy. Donald Trump has launched a trade war against China and Europe. He is challenging the Paris agreement on the fight against climate change. The European Union (EU) is facing the threat of Brexit at a time when problems about migration and the function of democracy find Western and Eastern European countries at odds. Bilateral trade agreements seem to be making progress but at the same time call into question the usefulness of the World Trade Organization (WTO). Negotiations on the taxation of multinational corporations are now underway, but are stalling due to national interests. In this context, the euro zone has made institutional progress, but this is difficult to implement, and has remained limited. Europe has a crucial role to play in putting in place the instruments that are indispensable for managing globalization, in ecological, commercial, fiscal and financial matters, but 
achieving this requires unity and a political impetus that are lacking today. How can the European project be relaunched?

Karl Whelan's introductory presentation focused on issues specific to the euro. The single currency appears to be a success: it has survived, it enjoys popular support, it has ensured price stability, it has put an end to exchange rate instability between the Member States, and a banking union is almost in place. Monetary policy has managed to be responsive. However, there have been widening imbalances between the Member States, a risk of default on public debts has emerged, and there is a growing risk of bank failures. Progress needs to continue: to rethink the fiscal policy rules, to create a capacity for fiscal intervention at the euro zone level, to provide a mechanism for restructuring public debt, to encourage banks to hold less of their own country's public debt by treating it as risky, to create a European deposit insurance scheme, and to clarify the ECB's function as lender of last resort vis-à-vis banks and governments. The case of Brexit shows that European integration is still at the mercy of nationalist movements.

Marek Dabrowski sketched an overview of the euro's history over the past 20 years. He welcomes the success of the single currency, but is concerned about the reluctance of certain countries to undertake the necessary reforms. He proposes deepening political integration, increasing the size of Europe's budget for financing joint projects, tightening market discipline to control fiscal policies, and simplifying and strengthening the application of fiscal rules. He considers that central and eastern European countries who are EU members but have not adopted the euro should set themselves the objective of doing so in the near future, which would simplify the EU's institutional architecture.

Several different viewpoints came out during the course of the discussion. According to Klaus-Jürgen Gern, the EU must choose between two paradigms. A fiscal union, with greater harmonization, coordination and risk-sharing, would, in this author's opinion, require fiscal restrictions in many countries, the strict application of fiscal rules, and structural reforms of the markets for goods and labour, which would need to be implemented at the country level. Maastricht 2.0 would be based on the diversity, competition and responsibility of each country. The non-assistance clause should be strengthened; its credibility would be enhanced by a stronger Banking Union with a European safety net, by breaking the link between the banks and the debt of their country of origin, and by creating a mechanism for the restructuring of public debts.

We ourselves are concerned about proposals that would weaken the economic policies of the Member States, decided democratically, to the benefit of European technocratic institutions, far removed from national 
realities. We recalled the example of the inappropriate fiscal policies imposed after the financial crisis. We believe it is dangerous to weaken the ability of governments to finance themselves and to rely on the financial markets to enforce sound fiscal policy. Some have argued that any project must take into account the existing political and economic disparities and differences between EU countries.

\section{Brexit}

Catherine Mathieu and Henri Sterdyniak presented an overview of the issues raised by Brexit. They analyse the positions of the European institutions and of the political forces in the United Kingdom, between the partisans of remaining in the EU, the partisans of a close partnership, and the partisans of a sharp break, possibly even without an agreement, a position that leads to a dead-end. So far, the results of the referendum have not resulted in the recession foretold, but to a slight slowdown in growth. The article presents various macroeconomic studies that assess Brexit's longterm impact on the British economy. The impact would be very negative if Brexit results in the closure of the UK, which would have lasting effects on the growth of labour productivity.

Given current events and the location of the conference, three presentations focused on Brexit's impact on Ireland. Martina Lawless analysed in detail the economic sectors and counties that would be hit by Brexit, in particular by a no-deal Brexit. There is extensive trade between the two parts of the island, which is local, rather than international. Small businesses and the agricultural sector (dairy, meat) face the greatest risk. The decrease in trade cannot be offset by an increase in foreign direct investment (FDI). Overall, the shock could lead to a 4-6\% drop in GDP for the Republic of Ireland.

The study by Christine Arriola et al. stressed that the Republic of Ireland is the EU country with the most extensive economic ties with the UK; in particular, the agricultural sector exports a lot to the UK; many of the intermediate goods used by Irish companies come from the UK, meaning that the production chains will have to be restructured; and the impact of relocating FDI would be positive, but weak. All in all, the long-term impact would only be a $2.3 \%$ drop in GDP.

Adele Bergin et al. compared three scenarios: an exit with a deal; an orderly exit without a deal; and a disorderly exit without a deal. In all three cases, the negative effect on trade is somewhat offset by a positive effect via FDI. Overall, the 10-year impact on the Republic of Ireland's GDP would be $2.6 \%, 4.8 \%$ or $5 \%$, depending on the scenario. 


\section{Monetary issues}

Rachel Slaymaker et al. analysed the arrears on mortgage payments in Ireland. They show that these depend on a household's income and level of debt, but that they are higher for variable rate loans and following a rise in interest rates, which will be problematic when the period of low interest rates comes to an end.

Roberto Pancrazi and Luca Zavalloni show that a country in difficulty may find itself faced with excessively high interest rates that cause it to go bankrupt at the expense of its creditors. This could justify public intervention (or international aid) to reduce the cost of the new debt it takes on. The article shows that this policy can be Pareto-improving, thus justifying the intervention of the International Monetary Fund (IMF) or the European Stability Mechanism (ESM) or the issue of senior debt securities.

Jérôme Creel and Mehdi El Herradi used a VAR model to analyse the link between monetary policy and income inequality. They find that a restrictive monetary policy tends to increase income inequality, with an effect that is especially significant for the peripheral countries (Spain, Greece, Italy, Portugal).

\section{Banking}

Ray Barrell and Dilruba Karim analysed the determinants of financial crises. Two variables play a central role: the current account deficit and the increase in property prices; and two variables play a stabilizing role: bank capital and bank liquidity. On the other hand, the role of an increase in bank credit is not highlighted. Some crises also remain unexplained. The authors assess that capital ratio requirements are the best tool for macroprudential policy, along with the control of credit quality, rather than quantity.

Hiona Balfoussia et al. analysed the relationship between the risk of default by the State and the risk of default by the banks. The fragility of public finances reinforces the impact of economic shocks through the channel of credit. This fragility can be avoided if capital requirements for banks are optimally adjusted. Applied to the Banking Union, the analysis shows that fragile countries may have an interest in a union, while countries with healthy public finances may suffer.

José Carrasco-Gallego used a DSGE model to compare the stabilizing properties of two instruments of macroprudential policy, the loan-to-value ratio (LTV) and the countercyclical capital buffer (CCB). He shows that each of these ratios can lead to inappropriate reactions for certain types of shocks and that what they indicate may be contradictory. 
Elizabeth Jane Casabianca et al. compared two methods for predicting banking crises: a logit econometric model and a machine-learning algorithm. It appears that the relevant variables are the external debt-to-GDP ratio, the credit-to-GDP ratio, inflation, and the 10-year US rate. Strong global growth increases the risk of a banking crisis. The public debt-to-GDP ratio has no predictive value. For developed countries, the algorithm predicts 53 crises out of 128 and gives 40 false alarms for 785 situations. In 2006, the risk of a crisis exceeded $50 \%$ for 25 countries; in 2017, it reached $40 \%$ for 9 countries (including the United Kingdom, Italy, the Netherlands and Switzerland).

\section{Finance}

Amat Adarov identified the financial cycles in 20 European countries from 1960 to 2015. These cycles are characterized by periods of expansion where imbalances are formed, followed by sharp contractions. These cycles are particularly important and synchronized for the countries in the core of the euro zone. They must be taken into account in analysing business cycles and the dynamics of public debt, but also in the organisation of the Banking Union and the Capital Markets Union and in relation to the objectives of monetary policy.

Robert Unger discussed the link between growth and development. According to an empirical analysis based on 34 developed countries from 1995 to 2014, it is household debt, rather than corporate debt, that plays a crucial role, initially promoting growth and then turning harmful beyond a certain threshold. The study does not show any difference between financing through bank credit or through the financial markets.

\section{Fiscal policy}

Beau Soederhuizen et al. used a VAR model to assess the fiscal multiplier based on the state of the financial cycle. The multiplier of government investment would be negative in times of rising financial stress, and positive, above 1 , in times of falling stress. Taking into account the business cycle, it appears that these effects are amplified during recessions and weakened during expansions. The multiplier for government consumption is lower and less dependent on the financial cycle.

Pedro Gomes and Felix Wellschmied analysed the functioning of the labour market in the public and private sectors in the United States, the United Kingdom, France and Spain. Workers make different job choices between the two sectors over the life cycle based on their risk aversion, their assets and the importance they attribute to job security and the differential in pensions. 
Harris Dellas et al. constructed a computable general equilibrium (CGE) model of the Greek economy, which incorporates an informal sector whose size varies according to tax rates and controls on financial flows. They show that fiscal consolidation has resulted in $50 \%$ growth in the informal sector, so even as official GDP has fallen by $26 \%$ (instead of the $18 \%$ initially envisaged), output has fallen by only $17 \%$.

Salvador Barrios et al. proposed an analysis of tax policy measures using a database on income tax reforms. These are described in detail in a microsimulation model; their macroeconomic impact is assessed using a VAR model, whose results are incorporated into a macroeconomic model. It appears that income tax cuts do have a positive effect on output and employment, but the increases in government revenue are insufficient to reverse the negative impact of lower taxes on the public purse.

Sebastian Weiske and Mustafa Yeter compared different mechanisms for fiscal transfers between Member States. These should make it possible to stabilize their economies, without inducing permanent transfers, without leading to the accumulation of debt, and without encouraging behaviour associated with moral hazard. There is a delicate trade-off between stabilization and the accumulation of debt. The authors propose introducing a cap on the net transfers received (or paid) by each country.

\section{Trade and external balances}

Kieran McQuinn and Petros Varthalitis show that the growth of the Irish economy, initially driven by the export sector, was spurred from 2004 to 2007 by a property bubble. The financial crisis has helped rebalance the economy in favour of the industrial sector. The recovery of the Irish economy is due not to structural reforms, but to the development of exports.

Cian Allen conducted an empirical study for the period from 1995 to 2015 that analyses the impact on current account fluctuations of changes in the financial balance of the government, the household sector, the corporate sector and the financial sector in the $\mathrm{G} 20$ countries. He shows that it is fluctuations in the public balance and the corporate balance (rather than in the household balance) that play a crucial role.

Pascal Jacquinot et al. used a dynamic general equilibrium model, with friction on the labour market, to analyse the impact of protectionist measures. These measures undermine employment both in the country implementing them as well as in the target country; third countries can benefit from a slight positive effect. On the other hand, measures hitting one of the euro zone countries have recessionary effects on the whole of the zone. 
John Lewis and Matt Swannell used a gravity model to analyse migration flows. They highlight the impact of the variables of distance, historic links, a common language, and the number of migrants already settled, but also macroeconomic variables, such as expected growth both in the country of origin (with a negative impact) and in the destination country (with a positive impact) and the flexibility of the labour market.

Tatiana Cesaroni et al. explain trends in inequality in European countries by separating the countries in the core from those in the periphery. Higher unemployment contributes to an increase in inequality in the two areas. An increase in GDP per capita reduces inequality in the core countries, but increases it in the peripheral countries. Trade and financial openness and taxation reduce inequalities in the peripheral countries. They have little impact in the core countries. The authors conclude that redistributive policies must be thought out at the national level.

Angelos Angelopoulos et al. analysed the impact of rent-seeking on economic activity and growth. Rent-seeking can be a stimulus to accumulating wealth and protecting against income shocks; however, it diverts productive activity, it immobilizes capital, and ultimately it leads to an increase in income inequality.

Tryfon Christou et al. consider that in countries with poor-quality institutions individuals devote part of their working time to rent-seeking. By distinguishing countries according to the quality of their institutions, they conclude that countries with better quality institutions have suffered less from the crisis and that it has led to a deterioration in the quality of their institutions.

\section{List of presentations}

Karl Whelan (University College, Dublin): The euro at 20: Successes, problems, progress and threats

Marek Dabrowski (CASE, Warsaw): The Economic and Monetary Union: Past, present and future

Catherine Mathieu and Henri Sterdyniak (OFCE, Paris): Brexit: Why, how, and when?

Martina Lawless (ESRI): Brexit and trade on the island of Ireland

Christine Arriola, Caitlyn Carrico, David Haugh, Nigel Pain, Elena Rusticelli, Donal Smith, Frank van Tongeren and Ben Westmore (OECD): The potential macroeconomic and sectoral consequences of Brexit on Ireland

Adele Bergin (ESRI), Philip Economides (ESRI), Abian Garcia-Rodriguez (ESRI and Trinity College Dublin) and Gavin Murphy (Department of 
Finance, Ireland): Ireland and Brexit: Modelling the impact of deal and no-deal scenarios

Rachel Slaymaker, Conor O'Toole, Kieran McQuinn (ESRI) and Mike Fahy (Trinity College Dublin, Department of Finance, Government of Ireland): Policy normalisation and mortgage arrears in a recovering economy: The case of the Irish residential market

Roberto Pancrazi (Warwick University) and Luca Zavalloni (Central bank of Ireland): Interest overhang: A rationale for the existence of sovereign lending mechanisms

Jérôme Creel (OFCE and ESCP Europe) and Mehdi El Herradi (University of Bordeaux-LAREFI): Shocking aspects of monetary policy on income inequality in the euro area

Ray Barrell and Dilruba Karim (LSE and Brunel University, London): Bank capital, excess credit and crisis incidence

Hiona Balfoussia (Bank of Greece), Harris Dellas (University of Bern and CEPR) and Dimitris Papageorgiou (Bank of Greece): Fiscal distress and banking performance: The role of macroprudential regulation

José A. Carrasco-Gallego (King Juan Carlos University, Madrid): Effectiveness of new macrofinancial policies

Elizabeth Jane Casabianca (Prometeia Associazione and Polytechnic University of Marche), Michele Catalano (Prometeia Associazione), Lorenzo Forni (Prometeia Associazione and University of Padua), Elena Giarda (Prometeia Associazione and University of Modena and Reggio Emilia) and Simone Passeri (Prometeia Associazione): An early warning system for banking crises: From regression-based analysis to machinelearning techniques

Amat Adarov (Vienna Institute for International Economic Studies): Financial cycles in Europe: Dynamics, synchronicity and implications for business cycles and macroeconomic imbalances

Robert Unger (Deutsche Bundesbank): Revisiting the finance and growth nexus - A deeper look at sectors and instruments

Beau Soederhuizen, Rutger Teulings and Rob Luginbuhl (CPB): Estimating the impact of the financial cycle on fiscal policy

Pedro Gomes (Birkbeck and University of London) and Felix Wellschmied (University Carlos III Madrid): Public-sector employment over the life

Harris Dellas (University of Bern), Dimitris Malliaropulos (Bank of Greece and University of Piraeus), Dimitris Papageorgiou (Bank of Greece) and Evangelia Vourvachaki (Bank of Greece): Fiscal multipliers with an informal sector

Salvador Barrios (European Commission, Joint Research Centre), Adriana Reut (European Commission, DG ECFIN), Sara Riscado (European Commission, Joint Research Centre and Portuguese Ministry of 
Finance) and Wouter van der Wielen (European Commission, Joint Research Centre): Dynamic scoring of tax reforms in real time

Sebastian Weiske and Mustafa Yeter (German Council of Economic Experts): An evaluation of different proposals for a European fiscal capacity

Kieran McQuinn and Petros Varthalitis (ESRI and Trinity College, Dublin): How openness to trade rescued the Irish economy

Cian Allen (Trinity College, Dublin): Revisiting external imbalances: Insights from sectoral accounts

Pascal Jacquinot (European Central Bank), Matija Losej (Central Bank of Ireland) and Massimiliano Pisani (Bank of Italy): Nobody wins: Protectionism and (un)employment in a model-based analysis

John Lewis and Matt Swannell (Bank of England): The macroeconomic determinants of migration

Tatiana Cesaroni (Ministry of Economics and Finance of Italy, MEF-DT), Enrico D'Elia (Ministry of Economics and Finance of Italy, MEF-DF) and Roberta De Santis (Istat and LUISS): Inequality in EMU: Is there a core-periphery dualism?

Angelos Angelopoulos (Athens University of Economics and Business and Greek Open University), Konstantinos Angelopoulos (University of Glasgow and CESifo), Spyridon Lazarakis (University of Glasgow), Apostolis Philippopoulos (Athens University of Economics and Business and CESifo): Rent-seeking worsens economic outcomes and increases wealth inequality

Tryfon Christou (Athens University of Economics and Business), Apostolis Philippopoulos (Athens University of Economics and Business and CESifo) and Vanghelis Vassilatos (Athens University of Economics and Business): Modelling rent-seeking activities: Quality of institutions, macroeconomic performance and the economic crisis 